\title{
Unusual cause of dysphagia
}

Hemanta K Nayak, ${ }^{1}$ Niraj Kumari, ${ }^{2}$ Samir Mohindra ${ }^{2}$

${ }^{1}$ Gastroenterology, All India Institute of Medical Sciences, Bhubaneswar, Orissa, India ${ }^{2}$ Department of

Gastroenterology, Sanjay Gandhi Postgraduate Institute of Medical Sciences, Lucknow, India

\section{Correspondence to}

Dr Hemanta K Nayak; drhemantnayak@gmail.com

Accepted 6 July 2021

\section{DESCRIPTION}

A 37-year-old man presented with a history of dysphagia to solids, anorexia and weight loss for 1 month without any pain during swallowing. He did not have any fever, night sweats and cough. He is non-diabetic with normal bodyweight, non-smoker and not on any immunosuppressive therapy. $\mathrm{He}$ is from a good socioeconomic status and did not have any high-risk behaviour. His HIV serology is negative.

Oesophagogastroduodenoscopy revealed a large deep ulcerated lesion in the mid-oesophagus at $30 \mathrm{~cm}$ from incisors without any luminal narrowing (figure 1). Biopsy from ulcerated site repeated twice did not reveal any malignancy, granuloma or viral inclusion body.

Contrast-enhanced CT (CECT) of thorax was done to look for ulcer extension and any associated mediastinal and paraoesophageal lymphadenopathy and lung parenchyma lesion. CECT of thorax revealed short segment mid-oesophageal wall thickening and mediastinal lymphadenopathy. Endoscopic ultrasonography (EUS) was done using linear array echo-endoscope (GF UCT 180; Olympus, Tokyo, Japan) showed subcarinal lymphnode of approximate size of $2.5 \mathrm{~cm}$, predominately hypoechoic with few thin internal septation (figure 2). EUS-guided fine-needle aspiration (FNA) was done using a 22-gauge needle (Expect FNA needle, Boston Scientific, Marlborough, Massachusetts, USA). Cytology showed loose collection of epithelioid cells, histiocytes, multinucleated giant cell in a background of necrosis (figure 3), Ziehl Neelsen stain-demonstrated acid-fast bacilli in an epithelioid cell granuloma(figure 3 insert). Gene Xpert MTB/RIF (Cepheid, Sunnyvale, California, USA) assay of aspirated material detected mycobacter tuberculosis, which was sensitive to rifampicin. He received 6 months of antitubercular therapy. His dysphagia improved and gained weight. Repeat oesophagogastroduodenoscopy at

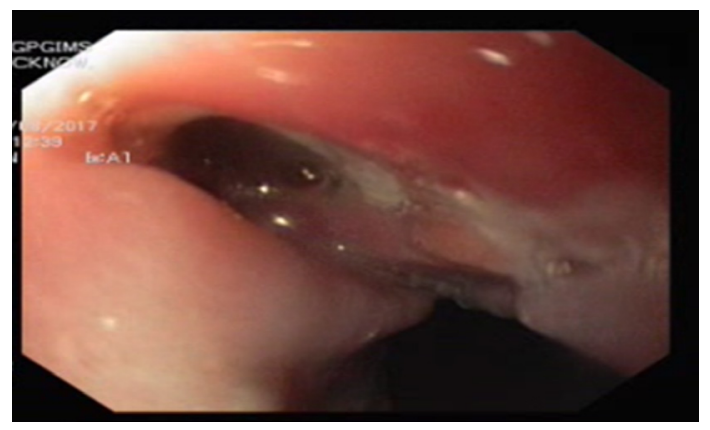

Figure 1 Oesophagogastroduodenoscopy revealed a large deep ulcerated lesion in the mid-oesophagus at $30 \mathrm{~cm}$ from incisors without any luminal narrowing.

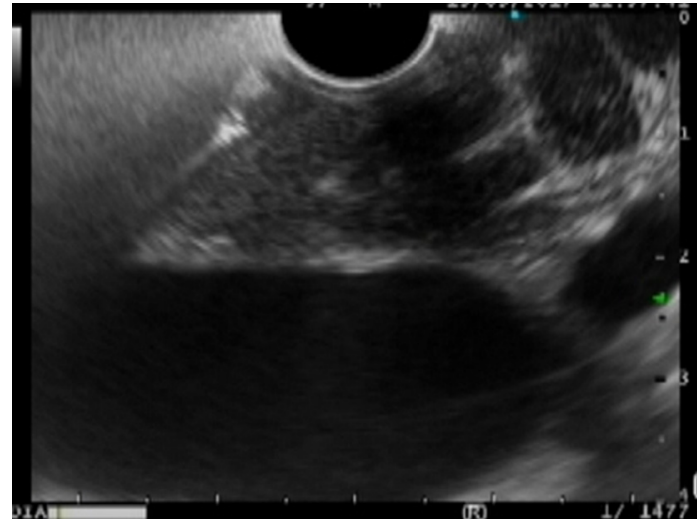

Figure 2 Linear echoendoscopy examination at mediastinum showed subcarinal lymph node of approximate size of $2.5 \mathrm{~cm}$, predominately hypoechoic with few thin internal septation.

completion of therapy revealed complete healing of previous oesophageal lesion.

Oesophageal tuberculosis is a rare condition, which contributes $1 \%-2 \%$ of all cases of gastrointestinal tuberculosis. ${ }^{1} \mathrm{Few}$ cases of oesophageal tuberculosis have been reported in the medical literature, and dysphagia being the most common symptoms.Mechanism of dysphagia can be multifactorial, can be due to compression by the surrounding tubercular perioesophageal lymph nodes, associated mediastinal fibrosis, ulceration and/or polypoidal lesions in the oesophagus or due to altered motility. ${ }^{2-4}$

Tubercular oesophageal ulcers most commonly located at mid-oesophagus and usually result from direct extension of infection from mediastinal

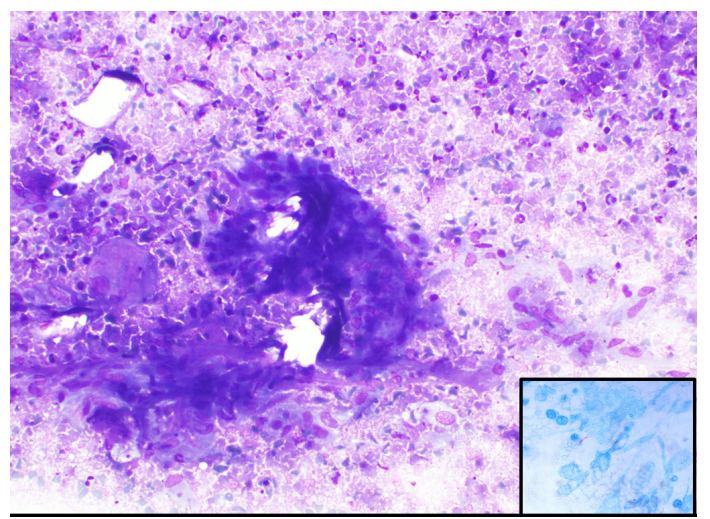

Figure 3 Cytology showed loose collection of epithelioid cells, histiocytes and multinucleated giant cell in a background of necrosis. Insert showing Ziehl Neelsen stain-demonstrated acid-fast bacilli in an epithelioid cell granuloma. 
nodes, and rarely the infection spread from the lungs or blood stream.

There are multiple differential diagnosis in patients with dysphagia and large oesophageal ulcers and list ranging from infective, inflammatory to malignant. Among infective causes, cytomegalovirus and herpes simplex virus oesophagitis are common usually occurs in the setting of immunosuppression or HIV infection. Oesophageal tuberculosis also an important

\section{Learning points}

Oesophageal tuberculosis is a rare condition and a multimodality diagnostic approach is useful, as endoscopic biopsy may sometimes be inconclusive.

- In oesophageal tuberculosis, dysphagia can occur because of various mechanisms like ulcerating and/or polypoidal luminal lesions, compression by perioesophageal lymph nodes, associated mediastinal fibrosis or altered motility.

- Endoscopic ultrasonography has been demonstrated to be an excellent tool for detection of tubercular mediastinal lymph nodes as well as guiding fine-needle aspiration, especially in situations where endoscopic biopsy is negative. differential diagnosis in developing world. Other possibilities includes malignant,crohns disease.

Most of the patients with oesophageal tuberculosis respond well to antitubercular therapy and surgery may be required in cases of fistulas, strictures and perforations. EUS plays a major role in the management, by detecting tubercular mediastinal lymph nodes as well as guiding FNA.

Contributors HKN and SM: Done the endoscopic procedure, involved in patient management and wrote the article; NK: contributed to pathology reporting.

Funding The authors have not declared a specific grant for this research from any funding agency in the public, commercial or not-for-profit sectors.

Competing interests None declared.

Patient consent for publication Obtained.

Provenance and peer review Not commissioned; externally peer reviewed.

\section{REFERENCES}

1 Chong VH, Lim KS. Gastrointestinal tuberculosis. Singapore Med J 2009;50:638-45.

2 Rana SS, Bhasin DK, Sharma V, et al. Dysphagia as the first manifestation of tuberculosis. Endoscopy 2011;43 Suppl 2 UCTN:E300-1.

3 Park JH, Kim SU, Sohn JW, et al. Endoscopic findings and clinical features of esophageal tuberculosis. Scand J Gastroentero/ 2010;45:1269-72.

4 Sharma M, Rafiq A, Kirnake V. Dysphagia due to tubercular mediastinal lymphadenitis diagnosed by endoscopic ultrasound fine-needle aspiration. Endosc Ultrasound 2015:4:348-50

Copyright 2021 BMJ Publishing Group. All rights reserved. For permission to reuse any of this content visit https://www.bmi.com/company/products-services/rights-and-licensing/permissions/

BMJ Case Report Fellows may re-use this article for personal use and teaching without any further permission.

Become a Fellow of BMJ Case Reports today and you can:

- Submit as many cases as you like

Enjoy fast sympathetic peer review and rapid publication of accepted articles

- Access all the published articles

Re-use any of the published material for personal use and teaching without further permission

Customer Service

If you have any further queries about your subscription, please contact our customer services team on +44 (0) 2071111105 or via email at support@bmj.com.

Visit casereports.bmj.com for more articles like this and to become a Fellow 